\title{
Water Management At Athens International Airport A CRITICAL APPROACH
}

\author{
Chilakos P. and Kavouras C. N. \\ Environmental Department, Athens International Airport, GR-19019 Spata, Greece, \\ petros.chilakos@aia.gr, harry.kavouras@aia.gr
}

\section{ABSTRACT}

The new Athens International Airport "Eleftherios Venizelos" (AIA) has been constructed in the heart of the Mesogaia plain, approximately 25 kilometres northeast of Athens. The airport, which has been constructed on agricultural land that was once used for the cultivation of vegetables, fruits, olives, and other fresh products, commenced operations in March 2001.

The Environmental Department (ENC) of AIA was established from the first day of the company's operation in summer 1996. The responsibilities of ENC are related to the Environmental Management System, aircraft noise, air quality, resources monitoring, water management, natural environment, waste management, cultural heritage, and community projects. AIA is the first $\mathrm{Hel}-$ lenic airport, with an Environmental Department that has been certified according to EN ISO 14001 since December 2000.

The airport and the activities directly and/or indirectly associated with its operations can have an environmental impact on water. In order to avoid such impacts, ENC closely monitors and takes initiatives regarding several water issues including: Ground water, Surface water \& Potable water Monitoring.

The purpose of this paper is to provide detailed information regarding water management issues, especially those related to monitoring programs. Several such programs are conducted on a regular basis (some having commenced even prior to airport operations, e.g., groundwater and surface water) where the different water media are sampled, sent to accredited laboratories, analysed for a selected suite of parameters, and checked for environmental compliance. If any of the waters tested are in non-compliance then a series of corrective measures are initiated

Groundwater sampling and analysis have been conducted on the airport site prior to airport opening. Results indicate that the parameters observed in exceedance to European legislation are attributed to agricultural practices that were prevalent prior to the airport construction rather than from airport operations

Surface water sampling has been conducted on the site since airport opening. The selected suite of parameters tested from specific locations show that no systematic elevated levels have been recorded. The initiatives of ENC, including training, environmental auditing of Airport's Third Parties, and remediation measures, have contributed to this outcome

The results from the potable water sampling and analysis, which is conducted in cooperation with EYDAP, indicate that water quality is in compliance with Greek legislation.

This paper will be of interest to researchers, practitioners, and policy-makers, since it provides useful information regarding the design, implementation, and outcome of water monitoring programs. 


\section{INTRODUCTION}

Athens International Airport (AIA) is located in the Mesogaia basin approximately 25 kilometres, northeast of Athens. The total area of the entire site is approximately $16.5 \mathrm{~km}^{2}$, of which $12.8 \mathrm{~km}^{2}$ comprise of the airport and ancillary facilities. The airport consists of a modern infrastructure, which includes modern main terminal and satellite buildings, a control tower, two parallel runways, a maintenance hangar, administration buildings, catering facilities, cargo terminals, and two sewage treatment plants.

The Municipalities of Spata, Markopoulo, Koropi and Artemis are located nearby at distances of approximately $2 \mathrm{~km}$ northwest, $2.5 \mathrm{~km}$ south, $3 \mathrm{~km}$ southwest and $1.5 \mathrm{~km}$ east respectively (Fig. 1). Adjacent land uses from the airport mainly consist of agricultural activities with vineyards being the primary cultivation crop. Olive, fig, almond, and peanut trees and a variety of seasoned vegetables are also grown. Irrigation of these fields is mostly conducted via manually dug wells and drilled water wells.

Athens International Airport "Eleftherios Venizelos" started operations in the spring of 2001. In 2003 the airport handled 164.000 aircraft movements, 12.151 .000 passengers and approximately 110.000 tons of cargo.

According to the annual results of the "Global Airport Monitor" independent survey of passenger satisfaction of the International Air Transport Association (IATA) for 2002, AIA was the world leader in the category of up to 15 million passengers per year. The airport is managed by Athens International Airport S.A. (AIA), which has 700 employees. In addition, more than 14.000 employees are employed by Third Parties (i.e., entities/companies operating at the airport, such as cargo companies, catering companies).

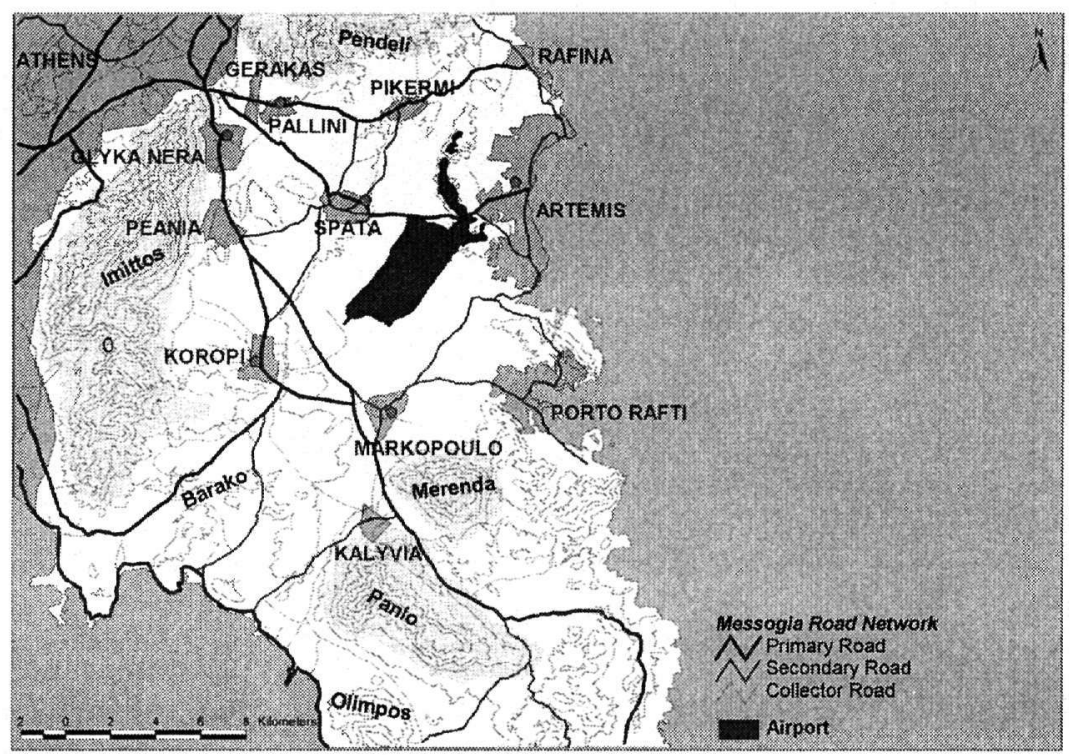

Figure 1. Location of AIA

\section{THE ENVIRONMENTAL DEPARTMENT}

The Environmental Department of Athens International Airport "Eleftherios Venizelos" was established from the first day of the company's formation in June 1996. Its establishment was a legal requirement of Ratifying Law 2338/1995 (Greek Government Gazette, 1995). The Environmental Department, which is the liaison between the airport company and the competent environmental authorities, is responsible for compliance with environmental legal terms, implementation of monitoring programs, submission of a bi-annual environmental report, etc. The Department is responsi- 
ble for all environmental activities and services across the airport site during construction and operation. It employs fourteen scientists and administrative personnel who focus on the Environmental Management System (EMS), aircraft noise, air quality and meteorology, resources management, water management, natural environment, waste management, cultural heritage and community projects. The environmental activities of AIA are described in detail in the annual Environmental Bulletin. Athens International Airport "Eleftherios Venizelos" is the first Hellenic airport, with an Environmental Department that has been certified according to EN ISO 14001 since December 2000.

\section{HYDROLOGICAL AND HYDROGEOLOGICAL SETTINGS}

\subsection{Hydrological Setting}

Two main hydrological basins exist in the area where the airport is currently located. Surface water generated in one basin is collected and discharges towards the Megalo Rema, Rafina, located approximately $5.2 \mathrm{~km}$ north of the airport site. Surface water in the second and much larger hydrological basin is collected and discharged to tributaries of the Erasinos river situated approximately 1 $\mathrm{km}$ south of the airport site (Fig. 2). Furthermore, smaller quantities of surface water discharge at the East perimeter of the airport.

The location of the airport site intersects several intermittent streams situated upstream and as a result in order not to divert or change the original hydrological regime to the area, a unique on site surface water drainage system consisting of sub drainage networks and several storm water outlets has been constructed. The majority of surface water generated across the airport site is collected in a $200.000 \mathrm{~m}^{3}$ main ponding area and then discharged at a controlled rate of $1.75 \mathrm{~m}^{3}$ to a tributary stream of the Erasinos river. The surface water network system has been developed in such a manner in order to stabilize and control the hydrological conditions in the Mesogaia area.

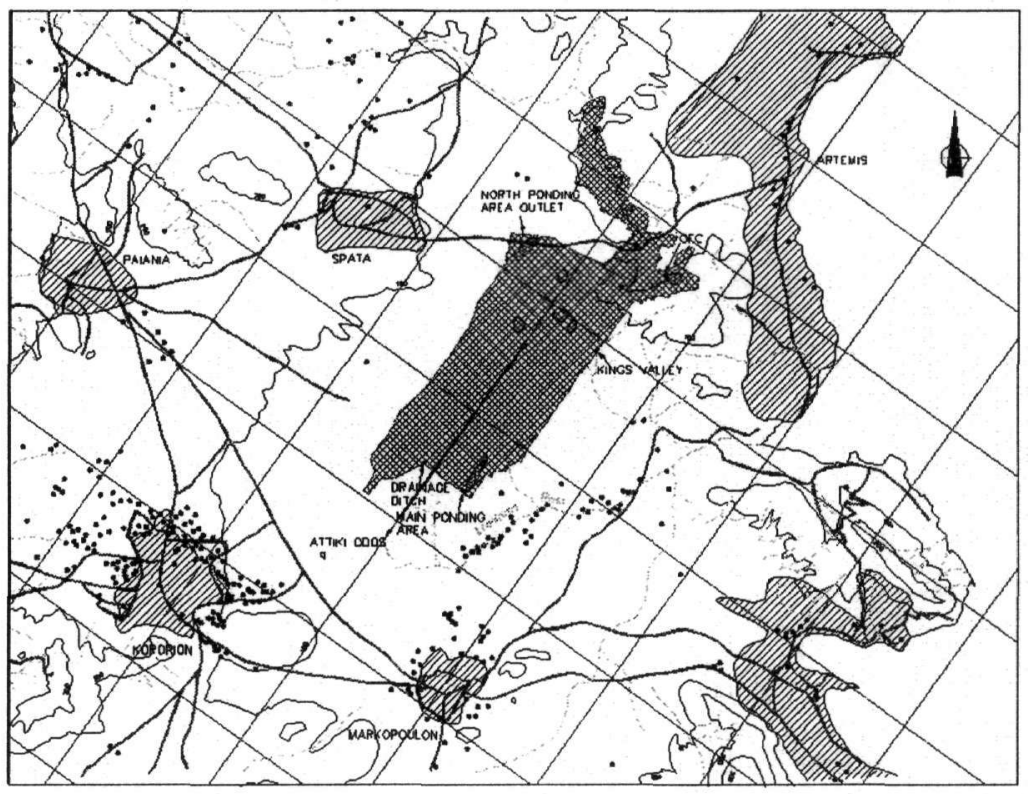

KEY

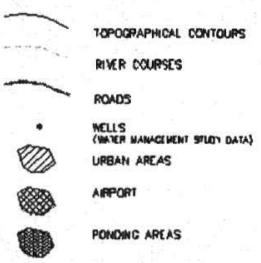

NoIrs

LOCA COOBOMATE STSEEU

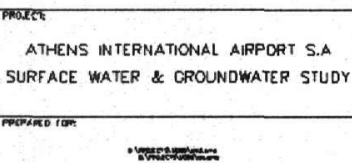

ATHENS INTERNATIONAL AIRPORT S.A

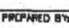

G.Saravokyris \& Partners

Figure 2. Main hydrological receptors adjacent AIA 


\subsection{Hydrogeological Setting}

Two main aquifer systems exist underneath the airport site: a) One upper aquifer that exists mainly in the quaternary and neogene deposits, and partially in the sericitic-quartzic shists. The aquifer is uniform semi confined and generally exists at depths approximately 25-30 meters below existing ground surface. b) A lower aquifer is a karst one that develops in the lower marble. It is estimated that the lower one is found at a depth of greater than 220 meters below existing ground surface. This aquifer is under pressure, and behaves as a confined aquifer since its piezometric surface rises up to few meters above the sea level. The Athenian schist that underlies the upper aquifer is believed to operate as potential seal preventing hydraulic communication of upper aquifer with karstified marbles and thus it confines the water head that is developed in the lower aquifer. In general, the groundwater levels indicate that groundwater flows within the upper aquifer in the broader vicinity and within the airport site, merge towards Erasinos valley at the SE of airport territory. Minor local alterations to the general trend that are observed at the $\mathrm{N}-\mathrm{NE}$ areas are limited and they are finally embodied to the general flow direction.

\subsection{Surface water drainage system}

The construction of the airport introduced many variables to the natural surface water drainage in the Mesogaia area. Specifically, surface water flow generated upstream would be interrupted because of the higher elevated airport site while the airport site paved infrastructure would lead to extremely elevated runoff coefficients. As a result, surface water quantities may not be able to be properly received by the natural downstream environment

Given these constraints the airport designed and developed an internal surface water drainage system which: a) accepts all upstream rainwater on the airport site and facilitates its flow through the site, b) is similar to natural background conditions, c) allows surface water runoff from the site to discharge at a controlled rate to avoid erosion to downstream receptors, d) uses oil/water separators in areas of potential environmental concern.

\subsection{Potable water distribution system}

All potable water supplied to the airport comes directly from the Greek State Public Utility Company EYDAP. Potable water enters the airport site from the nearby Spata - Loutsa pipeline and from there directed via an internal pipeline to the airports Water Supply Facility. This facility consists of two (2) concrete tanks, each having a capacity of $2.250 \mathrm{~m}^{3}$, which temporarily store the drinking water. Two parallel pipelines are connected from the tanks and run alongside the extent of the airport's main road. From the parallel pipelines, smaller distribution systems supply drinking water to the buildings.

Three (3) chlorination units have been strategically placed on the potable water pipeline to ensure that the water supplied to the Airport Community is of the highest quality. Recently an Ultraviolet unit was also installed at the Ramp Station building, which supplies water to all aircraft, in order to ensure that the airlines receive high quality water.

\section{WATER MONITORING PROGRAMS ${ }^{1}$}

\subsection{Groundwater monitoring}

Eight (8) monitoring wells have been installed across the airport site in order to monitor the subsurface water. Five wells designated.WO-1 through WO- 5 have been drilled in the overburden and three designated as WU-1, WU-2 \& OFCG in the bedrock. WO-1 and WO-2 have been drilled alongside the west perimeter fence line and are considered as upgradient wells. The remaining six wells have been drilled at different locations alongside and near the east perimeter fence line and are considered as downgradient wells (Fig. 3). Groundwater elevations in the overburden have been monitored and exist between $20 \mathrm{~m}$ and $30 \mathrm{~m}$ below ground surface. The bedrock wells have been measured and found to range between $40 \mathrm{~m}$ and $60 \mathrm{~m}$ below existing ground surface, indicating a lower semi-confined aquifer system.

\footnotetext{
${ }^{1}$ The information regarding monitoring and results refers to the period up to June 2004.
} 


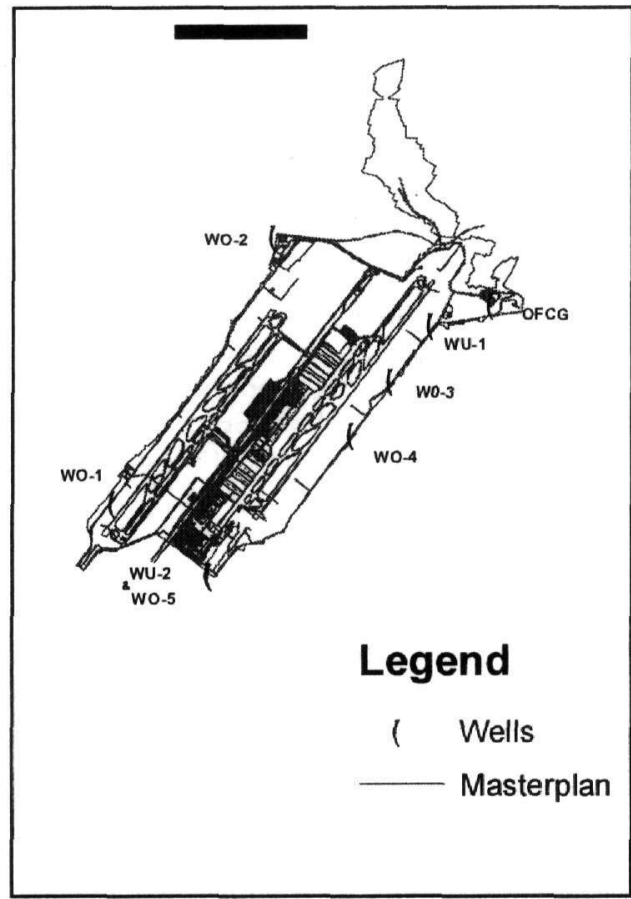

Groundwater sampling and analysis at the airport site commenced prior to Airport Opening in September 1998 in order to determine the background conditions. Groundwater sampling across the airport site occurs three times per year, in February, June and October. Since groundwater sampling commenced, a total of 18 monitoring programs have been conducted. All groundwater samples are sent to an independent laboratory for chemical analysis.

The parameters monitored include: $\mathrm{pH}$, Total Disolved Solids, Conductivity, Calcium, Magnesium, Potassium, Sodium, Chromium, Zinc, Arsenic, Lead, Nitrate, Nitrite, Ammonium, Phosphate, Sulphate, Chloride, COD, Total Coliforms, Faecal Coliforms, Escherichia Coli, Streptoccus facalis, Pseudomonas aeruginosa and Clostridium perfigens. Total Petroleum Hydrocarbons (TPH), and Oil and Grease (OG) measurements are also conducted, in order to examine the possibility of impact on the groundwater.

Figure 3. Ground water monitoring locations at AIA

\subsection{Surface Water Monitoring}

Surface water sampling and analysis across the airport site commenced in May 2001, one month after airport opening since the majority of outlets were completed just prior to opening. Sampling occurs on a regular basis from four main airport outlets usually after a rainfall period. Other outlets do not receive adequate amounts of water for proper sampling and analysis to successfully occur. Since surface water sampling commenced, a total of thirty-eight (38) monitoring programs have been conducted. All surface water samples are sent to an independent laboratory for chemical analysis.

The parameters monitored include: $\mathrm{pH}$, TDS, Conductivity, Chromium, Zinc, Arsenic, Cadmium, Mercury, Lead, Cobalt, Benzene, Ethylbenzene, Toluene, and Xylene (BTEX), TPH, OG, TBC 22/37, Total Coliforms, Faecal Coliforms, Escherichia Coli, Streptoccus facalis, Pseudomonas aeruginosa, and Clostridium perfigens. When needed, additional parameters are analysed.

\subsection{Potable Water Monitoring}

Since 2001, AIA and EYDAP have developed a close working relationship with respect to the airport's potable water system. Once per month EYDAP representatives obtain potable water samples from four strategic locations. Furthermore, on a weekly basis, EYDAP also takes samples from the main water line that supplies drinking water to the airport site. All potable water samples are analysed by EYDAP's laboratory.

The parameters monitored on a regular basis by EYDAP include: turbidity, residual free chlorine, Total Coliforms, Faecal Coliforms, Escherichia Coli, Streptoccus facalis, Pseudomonas aeruginosa, and Clostridium perfigens.

\section{RESULTS AND DISCUSSION}

From the existing data set, which mainly involves approximately three (3) years of AIA operation, it can be concluded that very limited additional environmental stresses on the water have been introduced in an area where land and water were significantly affected by tremendous population growth during the last decades. 


\subsection{Groundwater monitoring}

The concentrations for the parameters monitored in the groundwater across the airport site are compared to water quality criteria for the water intended for human consumption. These criteria are based on the new Directive 98/83/EC, which has replaced the older one 80/778/EEC. The new directive has come into effect since December 25, 2003, and has been transposed in Greek legislation by the Common Ministerial Decision Y2/2600/2001 Off. Gaz. 892B/11-7-2001.

Table 1 represents typical groundwater monitoring data for a monitoring date in 2004.

Table 1. Groundwater monitoring programme data 2004

\begin{tabular}{|c|c|c|c|c|c|c|c|c|c|}
\hline Parameter & Units & wo-1 & WO-2 & Wo-3 & wo-4 & Wo-5 & WU-1 & WU-2 & OFCG \\
\hline $\mathrm{pH}$ & - & 6,9 & 7,1 & 7 & 6,8 & 7 & 7 & 7,1 & 7,2 \\
\hline TDS & $\mathrm{ppm}$ & 624 & 2240 & 2420 & 1490 & 652 & 572 & 515 & 822 \\
\hline Conductivity & $\mu \mathrm{s} / \mathrm{cm}$ & 891 & 1570 & 1690 & 2130 & 932 & 817 & 735 & 1174 \\
\hline Calcium & ppm & 113 & 107 & 107 & 229 & 113 & 152 & 96 & 98 \\
\hline Magnesium & ppm & 37,7 & 94 & 67,5 & 56,5 & 42,5 & 7,8 & 41,3 & 27,6 \\
\hline Potassium & $\mathrm{ppm}$ & 1,92 & 3,05 & 2,11 & 2,9 & 2,34 & 1,21 & 2,28 & 2,04 \\
\hline Sodium & ppm & 60 & 304 & 482 & 194 & 62 & 49 & 61 & 128 \\
\hline Chromium & $\mathrm{ppb}$ & nd & nd & nd & nd & nd & nd & nd & 6 \\
\hline Zinc & $\mathrm{ppb}$ & nd & 40 & nd & 30 & nd & nd & nd & 420 \\
\hline Arsenic & $\mathrm{ppb}$ & nd & nd & nd & nd & nd & nd & nd & nd \\
\hline Lead & $\mathrm{ppb}$ & nd & nd & nd & nd & nd & nd & nd & nd \\
\hline Nitrate & $\mathrm{ppm}$ & 41,2 & 46,8 & 112 & 92,5 & 91,4 & 15 & 38 & 22,4 \\
\hline Nitrite & ppm & 3,75 & nd & nd & nd & nd & nd & nd & nd \\
\hline Ammonium & ppm & 0,17 & 0,06 & 0,05 & 0,06 & 0,08 & 0,05 & 0,06 & 0,06 \\
\hline Phosphate & ppm & 0,12 & 0,11 & 0,22 & 0,07 & 0,12 & 0,09 & 0,1 & 0,05 \\
\hline Sulphate & ppm & 220 & 202 & 265 & 142 & 120 & 59 & 56 & 0,05 \\
\hline Chloride & ppm & 23 & 597 & 447 & 540 & 89 & 59 & 94 & 229 \\
\hline$C O D$ & $\mathrm{ppm}$ & 1 & 30,7 & 43,9 & 30,7 & 87,7 & 1,2 & 0,7 & 3,2 \\
\hline TPH & ppm & 0,1 & nd & nd & 0,1 & 0,15 & nd & nd & nd \\
\hline Oil \& Grease & ppm & 0,1 & 0,15 & 0,1 & nd & 0,15 & nd & nd & nd \\
\hline Total Coliforms & $\mathrm{cfu} / 100 \mathrm{ml}$ & 0 & 20 & 0 & 0 & 60 & 0 & 100 & 0 \\
\hline Faecal Coliforms & $\mathrm{cfu} / 100 \mathrm{ml}$ & 0 & 0 & 0 & 0 & 60 & 0 & 100 & 0 \\
\hline E.Coli & $\mathrm{cfu} / 100 \mathrm{ml}$ & 0 & 0 & 0 & 0 & 12 & 0 & 0 & 0 \\
\hline Strep. faecalis & $\mathrm{cfu} / 100 \mathrm{ml}$ & 0 & 0 & 0 & 0 & 0 & 0 & 0 & 0 \\
\hline Pseud. aerug. & $\mathrm{cfu} / 100 \mathrm{ml}$ & 1600 & 340 & 1000 & 800 & 3500 & 800 & 2000 & 0 \\
\hline Clost. perfigens & $\mathrm{cfu} / 100 \mathrm{ml}$ & 800 & 500 & 1500 & 300 & 16000 & 800 & 1800 & 0 \\
\hline
\end{tabular}

$\mathrm{nd}=$ non detected

Elevated concentrations of nitrate, sodium, calcium, and magnesium were detected in several groundwater-monitoring wells that exceeded the water quality criteria established by the European Union (Fig. 4). Theses exceedances have been noted since 1998 and hence were present prior to airport construction and are due to natural background soil/bedrock conditions, anthropogenic effects mostly from agricultural activities and leaking septic systems. No other systematic exceedances have been observed. 


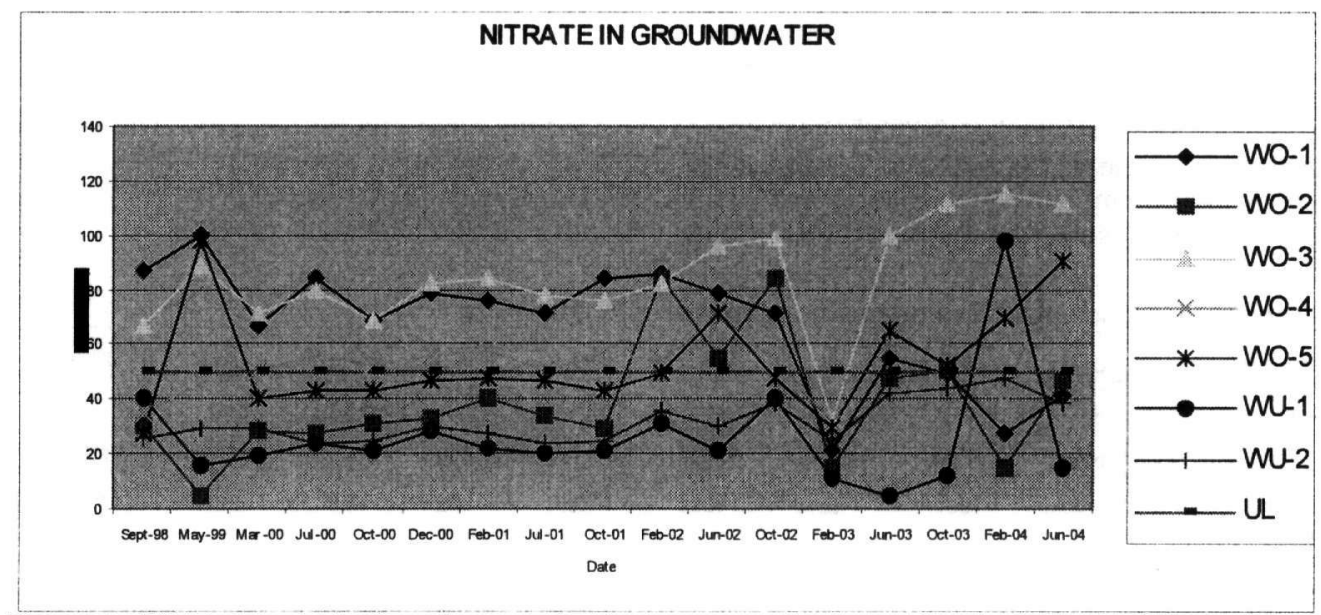

Figure 4. Nitrate concentrations in groundwater.

\subsection{Surface water monitoring}

Currently, no relevant legislature for surface water discharge from the airport site exists. The airport uses the Thessaloniki Prefecture Decision $\Delta Y$ 22374/91/94 (Off. Gaz.82B 10/2/94) as a guideline. This legislation applies to effluent emissions to natural receptors in Thessaloniki. In general, no systematic elevated levels have been recorded.

\subsection{Potable water monitoring}

The concentrations for the parameters monitored in the potable water across the airport are compared to the new Directive 98/83/EC, which has replaced the older one 80/778/EEC. All tested parameters were found in acceptable concentrations, when compared to the legal requirements for potable water.

\section{INITIATIVES OF THE ENVIRONMENTAL DEPARTMENT}

A number of initiatives of the Environmental Department ensure that problems are prevented or that challenges are addressed in the most efficient manner including:

a) continuous training to third parties that handle hazardous products,

b) continuous training to airport security personnel to identify suspicious or illegal waste management practices,

c) continuous site inspections to third parties that handle hazardous products,

d) site inspections at areas of potential concern,

e) in-situ remediation of impacted areas using advanced bioremediation substances.

In addition, the Environmental Department distributes the following leaflets to Airport users: "Potable Water", "Hazardous Waste Management", and "Protecting our Environment". The purpose of the leaflets is to i) inform the Airport Community about environmental issues, ii) provide basic guidelines regarding responses to environmental challenges, and iii) increase environmental awareness.

The installation of additional groundwater monitoring wells in areas where maintenance activities are taking place will be considered in the future, while one of the 2004 EMS goals is to introduce the Geographic Information Systems (GIS) to all on-site water media. Finally, given the continual development of the airport and more stringent legislation additional parameters (various hydrocarbons) will be tested. 


\section{CONCLUSIONS}

Since 1998, AIA has developed and implemented a sophisticated water sampling program for several water media across the airport site (i.e., groundwater, surface water and potable water). The parameters selected for the sampling program have been chosen in order to determine if any environmental impact exists, the extent of the potential impact, and the possible source.

Regarding groundwater a few parameters were above the limits. However, this impact existed prior to airport operations and is due to natural background soil/bedrock conditions, anthropogenic effects mostly from agricultural activities and leaking septic systems. For surface water, no systematic elevated levels have been recorded. Finally, no exceedances were found in the potable water system. This was due to the quality of water obtained from EYDAP, and the use of an efficient chlorination system (and more recently a Ultraviolet unit) across the airport site.

The available short period of AIA operation and monitoring has involved practices and methodology compliant with legal and environmental requirements. Regular and in some cases more extensive monitoring is also recommended.

Overall, the Environmental Department plays a key role in conducting environmental audits, providing training to the airport community, employing innovative bioremediation techniques in order to avoid off-site impact to downstream natural receptors, and communicating with the airport community.

\section{AGKNOWLEDGEMENTS}

The authors would like to thank their manager Dr. P. Karamanos for proof reading this paper and providing some thoughtful insights. Furthermore we would also like to thank Mr. I. Karavokiris for his most useful contribution to this paper.

\section{REFERENCES}

Karavokyris, G. \& Partners, 2003. Surface water and ground water study. Water quality data, sampling and analysis report.

Chilakos, P. 2003. Water Management Report. Unpublished Internal report.

Kavouras, C. N. 2003. Environmental Audit Manual and Checklist for AIA. Unpublished Internal Report.

Kavouras, C. N. 2002. Strategy to Enforce Proper Environmental Behaviour of Third Parties. Unpublished Internal Report.

NAMA Consulting Engineers and Planners, 1998. Hydrological study and investigation programme at Athens International Airport, Spata, Greece. 